\title{
Changes in the occurrence range of hosts cause the expansion of the ornate dog tick Dermacentor reticulatus (Fabricius, 1794) in Poland
}

\author{
Grzegorz Karbowiak ${ }^{1}$
}

Received: 11 May 2021 / Accepted: 20 October 2021 / Published online: 17 November 2021

(c) The Author(s) 2021

\begin{abstract}
The turn of the twentieth and twenty-first centuries brought changes in the range of many pathogens and their vectors. An example is the Dermacentor reticulatus tick. So far, relatively not numerous, their range of occurrence was divided into two areas-western European and eastern. An increase in the number and spread of this tick has been observed since the 1990s. Possible causes may be changes in the average summer and winter temperature in Europe and changes in the structure and use of agricultural land and forest areas. Changes in the distribution and abundance of mammals which are the main hosts of adult ticks, such as elk Alces alces, red deer Cervus elaphus, raccoon dog Nyctereutes procyonoides and the red fox Vulpes vulpes, may be important factors as well. Increase in the size of the hosts populations correlates with the subsequent increase in numbers and the emergence of new tick populations. The food base of adult ornate dog ticks is a large herbivorous mammal population. Predatory mammals can support the expansion of the ticks. The expansion of the raccoon dog in the west correlates with the emergence of new D. reticulatus populations west to the previous border of the eastern range of their occurrence. The intrusion of foxes into inhabited areas may be a synanthropic factor that supports the rise of new tick populations in urban agglomerations.
\end{abstract}

Keywords Deer $\cdot$ Dermacentor reticulatus $\cdot$ Carnivores

\section{Introduction}

Ticks belong to the most dangerous blood-sucking arthropods targeting humans and pets. Their importance is emphasized by the fact that their harmfulness is not limited to the immediate consequence of blood feeding, but they are carriers of causative agents of several vector-borne diseases. Approximately 900 species of ticks are known worldwide, about 40 of which occur in Europe (Siuda 1993; Guglielmone et al. 2014; Estrada-Peña et al. 2017). As parasites directly dependent on environmental influences, ticks respond adequately to climate change with changes in their distribution and life cycles (Gray et al. 2009). The example among European species is the ornate dog tick Dermacentor reticulatus (Fabricius, 1794) (Bullová et al. 2009; Karbowiak

Grzegorz Karbowiak

grzgrz@twarda.pan.pl

1 Witold Stefański Institute of Parasitology, Polish Academy of Sciences, Twarda 51/55, 00-818, Warsaw, Poland and Kiewra 2010; Akimov and Nebogatkin 2011; Karbowiak 2014). The beginning of the expansion of this species occurred during the first decade of the twenty-first century, when an increase in the size of the existing populations and the emergence of new outbreaks in places previously free of these ticks were registered (Földvári et al. 2016).

\section{Geographic range and environment of Dermacentor reticulatus until the end of the twentieth century}

The ornate $\operatorname{dog}$ tick $D$. reticulatus inhabits open areas or areas slightly overgrown with trees and shrubs, moderately moist. It prefers natural deciduous forests with watercourses or large stagnant reservoirs. Therefore, these ticks are most abundant in riparian forests on the banks of rivers and lakes and in meadows at the edges of forests, at a relatively high level of groundwater, which prevents them from drying out (Siuda 1993; Földvári et al. 2016). 
Ornate dog ticks occur throughout the temperate zone of Eurasia, from England and France to the Yenisei basin in Siberia. According to Immler (1973), the range of the tick's occurrence is determined by the area characterized by spring rainfall from 400 to $1000 \mathrm{~mm}$ and limited by an isotherm of $20-22{ }^{\circ} \mathrm{C}$ for the summer. Until the beginning of the twentyfirst century, the northern boundary of the range ran at $56-57^{\circ}$ $\mathrm{N}$ latitude, and the southern one at $50^{\circ} \mathrm{N}$ latitude (Siuda 1993, 1995). The area where the tick was found is characterized by a phenomenon that is unheard of in other European ticks and is inherently completely rare. It is divided into two parts- the socalled western European area and eastern area (Immler 1973; Siuda 1993, 1995; Siuda et al. 1997). The western part of the range covered populations from France (Upper Southern Jurassic, Rhone Valley, Northern French Alps, Ardennes) (Gilot et al. 1973; Panas et al. 1976; Martinod and Gilot 1991) to the eastern part of Germany (Taurus Mountains, Black Forest, Bavaria) (Mačička et al. 1956) and most east of Leipzig (Bauch 1990). The ornate dog tick was most numerous in the east wing of the eastern part of Poland, through Belarus and along the European part of Russia to Siberia. The northern boundary of the range in Russia runs through Moscow, Ivanovo, Ryazansky, Sverdlovsk, Tyumen, part of the Omsk region, the cities of Novosibirsk and Kanski to the Kemerovo region (Ravdonikas et al. 1968; Chigirik and PleshivtsevaEroshkina 1969). In the Asian part of Russia, numerous populations extend to the North Caucasus and Eastern Transcaucasia. The southern border of the eastern range included the mountains of Crimea, pre-Caucasus, eastern Kazakhstan and in Kyrgyzstan the mountains of western Altai (Mačička et al. 1956). In Belarus, D. reticulatus was common in Polesye (Savitsky and Kulnazarov 1988). The populations of Polesye are directly related to the populations of $D$. reticulatus in Podlasie in Poland and should be treated jointly. In Ukraine, this tick was detected in the central part of the country, including the Kiev region and the Transnistrian Lowland (Brovko 1966; Akimov and Nebogatkin 2002). Part of the eastern range also included populations found in the eastern part of Slovakia and Romania, where $D$. reticulatus was relatively common (Metianu 1951).

The area in Europe where D. reticulatus was absent was approximately triangular, with the northern edge running along the Baltic coast and arms extending from central Germany, from meridian $12-13^{\circ} \mathrm{E}$ to meridian $19^{\circ} \mathrm{E}$ in Poland. The southern arms of the triangle converged, reaching the southern border of Hungary (Karbowiak and Kiewra 2010).

\section{Changes in the distribution of Dermacentor reticulatus in recent decades}

The area of $D$. reticulatus occurrence described above did not change from the first descriptions of this tick species until the turn of the 1970s and 1980s.In the 1980s, there was a tendency for this species to expand to the mentioned areas and to occupy new localities. At the same time, the number of previously known populations has increased significantly. It was visible all over Europe (Földvári et al. 2016). Until the 1970s, this tick was a rare species in Germany (Immler 1973). In recent years, it has appeared in large numbers in Saxony, Saxony-Anhalt, Brandenburg, and the population in Hesse and Bavaria has increased (Dautel et al. 2006). The emergence of new populations of $D$. reticulatus in eastern Germany is accompanied by the emergence of new populations in western Poland. There have been new outbreaks in the Dolnośląskie and Lubuskie voivodeship (Nowak 2011; Kiewra and Czułowska 2013; Cuber et al. 2013; Ciebiera et al. 2021). New locations also appeared in Great Britain, north of the previously known towns (Wall 2012). The northern border of the eastern range of the tick reached Lithuania at the beginning of the twenty-first century. It has now been shifted north to Latvia, where new populations have been discovered in places where $D$. reticulatus had not been present before (Paulauskas et al. 2015).

At the western borders of the eastern range, D. reticulatus became more numerous. In Poland, it was observed in Podlasie and Masuria and in the Lublin region (Karbowiak and Kiewra 2010; Zając et al. 2020). It also appeared in recreational areas of large urban agglomerations, where it had not been observed previously. To the west of the compact range, new populations are also emerging. New populations appeared in central Poland, far west of the Vistula (Mierzejewska et al. 2016). In Hungary, the species has been continuously expanding for three decades. Currently, it occurs throughout the country and is much more numerous (Sréter et al. 2005; Földvári et al. 2016). Like in Hungary, the expansion of the tick has been observed in Ukraine, where new populations have emerged south of the current range limit (Akimov and Nebogatkin 2011).

In Slovakia and the Czech Republic, D. reticulatus was a rare species until the 1980s. It was registered along the Danube and Bodrog rivers and on the border with Ukraine (Daniel et al. 1986). Only in the last decade, new populations appeared at a rapid pace (Labuda et al. 1989; Bullová et al. 2009). Apart from changes in distribution, an increase in the number of ticks was observed in the villages where it had been found as a rare species (Široký et al. 2011).

\section{Factors determining the $D$. reticulatus distribution and reasons for changing its occurrence range}

The reasons for the division of the area of distribution of D. reticulatus into two separate areas so far are unknown. Possible explanations relate to natural conditions and climate change. Since there are no geographic barriers 
between the natural forest and meadow ecosystems of the Palearctic in the area that extends along the strip between the 50th and 55th parallel from France to the Urals, there is no reason to believe that this was the natural case. It can be assumed that human activity resulted in the factors causing the disappearance of $D$. reticulatus populations in this area. Perhaps it is related to the intense melioration and liquidation of small watercourses and reservoirs, and the reduction of the host populations (Daniel et al. 1986). However, this assumption is not supported by any evidence. Intensive human activity took place throughout the entire distribution range of $D$. reticulatus without causing its extinction. As records of the presence of the tick date back to the mid-nineteenth century (Koch 1844), it is currently impossible to state when the withdrawal of D. reticulatus from western Germany, central Poland and Slovakia occurred in this process.

Natural causes may be related to Europe's climatic structure. Central Poland is a transition zone between the oceanic and continental climate, and in this area, humid air masses flowing out of the Atlantic Ocean collide with dry masses of continental origin (Błażejczyk 2006). This, in turn, affects vegetation and the animal world associated with it. In Poland, there is a transition zone between plant communities and fauna associated with deciduous forests typical of the oceanic climate, and communities associated with coniferous forests typical of the continental climate. For this reason, the range boundaries of many species of animals and plants run through the center of Poland. It is estimated that $52 \%$ of species occurring in Poland are of a transitional nature, i.e., they occur both to the east and west of borders of the country. Other species end or begin their occurrence in Poland (Matuszkiewicz 2006).

These reasons do not fully explain the gap in the presence of $D$. reticulatus, as its eastern range ends in Poland, and reappears farther west. The same does not apply to the distribution of the common tick Ixodes ricinus Linnaeus, 1758, the range of which is uninterrupted.

Climate change related to global warming is mentioned among the factors responsible for the spread of the ornate dog tick to new areas. Secondly, attention is paid to environmental changes caused by human activity-changes in the use of agricultural and forest land, and the import of ticks during travel and trade (Földvári et al. 2016). Ecological corridors play an important role in linking remote areas with the features of natural ecosystems. River valleys are the most common. They are an attractive habitat for $D$. reticulatus, but also represent migration routes for wild animals and their pathogens. Ecological corridors are important both on a national scale, allowing ticks to spread along with their hosts, and on a smaller scale, enabling the colonization of parks and green areas within cities (Supergan et al. 2008; Zając et al. 2021). Numerous observations suggest that the ornate dog tick and common tick are characterized by a certain plasticity and the ability to occupy environments changed by human activity. Széll et al. (2006) even considered $D$. reticulatus as anthropophilic. In urbanized areas, ticks mainly inhabit recreational areas characterized by trees and / or shrub vegetation. In city parks, these are most often areas made up of natural plant communities, with at least partially preserved original vegetation (Karbowiak and Siuda 2001; Supergan and Karbowiak 2009).

\section{The role of hosts in changes in the geographic range of $D$. reticulatus}

Changes in the number and distribution of adult tick hosts may also be important. The role of mammals in the spread of pathogens is not new; in Poland, it was demonstrated in large ruminants infected with internal parasites (Dróżdż et al. 2002; Karbowiak et al. 2014). Migratory birds are an important factor in the particular distribution of ticks (Hasle 2013). On the other hand, the potential role of the lack of suitable hosts in limiting the distribution range of ticks to particular regions was assumed by Daniel et al. (1986) even before the phenomenon of $D$. reticulatus extending its geographical range was noticed. The most important hosts of ornate dog ticks are the European bison Bison bonasus (Linnaeus, 1758), European elk Alces alces (Linnaeus, 1758), red deer Cervus elaphus Linnaeus, 1758, roe deer Capreolus capreolus (Linnaeus, 1758), wild boar Sus scrofa Linnaeus, 1758, red fox Vulpes vulpes (Linnaeus, 1758), and raccoon dog Nyctereutes procyonoides (Gray, 1834) (Nowak-Chmura 2013). The number and size of the population of these mammals in Poland have increased in recent decades due to the protection and restoration of natural habitats. However, it seems that four of them are involved in extending the geographical range of $D$. reticulatus - European elk, red deer, red fox, and raccoon dog. These mammals play an important role as hosts of adult ticks, their infestation is high, they are relatively common, and are able to migrate on long distances. The range of $D$. reticulatus hosts is of course wide, but the role of other hosts is limited due to low infestation with ornate dog ticks compared to those mentioned above, low mobility or small population size. In some cases, like for the wild boar, there host role is difficult to demonstrate due to the lack of relevant data on tick infestations.

\section{European elk Alces alces}

After World War II, the elk turned out to be sparse in Poland as free-living populations occurred along the Biebrza River in eastern Poland. In addition, it was kept in breeding in the Kampinos Forest. From the 1950s, its populations and area 
of distribution began to gradually increase, mainly in the eastern part of the country. At the beginning of the 1970s, the presence of 4-6 thousand elks in Poland was estimated. European elk growth was possible thanks to its successful reintroduction in the Kampinos National Park in 1956 and the emigration of animals from beyond the eastern border (Pucek and Raczyński 1983; Zalewski et al. 2018). The upward trend was not stopped by the beginning of hunting in the mid-1970s. In 1981, the number of elks in Poland was estimated at 6.2 thousand individuals. In the 1990s, a temporary breakdown in the number of elks and changes in the distribution of the elk population in Poland were observed. In 1999, three provinces of north-eastern Poland remained a significant mainstay: Białystok, Łomża and Suwałki, and the Chełm Province, lying at some distance. At that time, each of them harbored of over 100 elk individuals.

The reconstruction of the elk population in Poland, initiated at the beginning of the twenty-first century, was possible mainly due to local decisions refraining from hunting. Elk numbers increased mainly in the eastern part of the country. This mainly concerned Podlasie, where the density in spring 2008 was estimated at about $2-5$ elk individuals per 1000 ha of forest, and the Lublin region, where the density was estimated at 2-4 specimens / 1000 ha. Elk were also relatively numerous in most districts of Mazovia (1-3 individuals / $1000 \mathrm{ha}$ ), while retreatments of refuges in southern and western Poland were much slower (Kamieniarz and Panek 2008). The entire population of elk in Poland in 2008 was estimated at 6000, in 2011 at 8000, and in 2017 at 20,000 individuals. The largest number is found in hunting districts in the northeastern part of the country, where the elk density reaches 10 or more individuals per 1000 ha of forests (Kamieniarz and Panek 2008; Budny et al. 2011; Zalewski et al. 2018).

\section{Red deer Cervus elaphus}

At the end of the 1980s, red deer were found in most forest complexes in Poland. However, the density of these animals varied greatly. Quite high numbers were recorded in northern, western and southern Poland, lower in the central regions and most voivodeships in the east of the country. A constant increase in the number and size of the red deer population has been observed in every region of Poland. In the early 1990s, the number of red deer in the entire country was estimated at 85,000-90,000, and in the spring of 2007 , at 154,000 individuals, almost twice as many. The highest density was recorded in the west and south of the country. In turn, the lowest densities of red deer were found in the center of the country, which is characterized by low forest cover. In 2016 , the number of red deer reached 220,000. The increasing density is accompanied by behavioral changes-with a large number of red deer, they began to occur even in agricultural areas with low forest cover (Zalewski et al. 2018).

\section{Raccoon dog Nyctereutes procyonoides}

The raccoon dog breed comes from the forests of Northeast Asia. In 1928-1957, raccoon dogs were introduced as fur animals to the European part of the former Soviet Union. Raccoon dogs were intentionally released in Estonia, the St. Petersburg region and the Kola Peninsula. In some areas, raccoon dogs may have escaped from livestock farms and these individuals have created new populations (Heltai et al. 2000). Escaped and released animals began to colonize new areas to the north and west. Wild raccoon dogs soon appeared in Finland in 1935. In the 1950s, the first raccoon dogs appeared in Poland and Romania, in the 1960s in Germany, Czechoslovakia, Hungary and Austria, in the late 1970s in France, in 2001 in the Netherlands (Nowak and Pielowski 1964; Kauhala 1996; Kauhala and Kowalczyk 2011; Mulder 2012). By 1984, raccoon dogs had colonized an area of over $1,400,000 \mathrm{~km}^{2}$. The European range of raccoon dogs is systematically growing, at a rate of 40 to 120 km per year (Kauhala 1996; Kauhala and Kowalczyk 2011). The current range of raccoon dogs in Europe includes the European part of Russia, Finland (except Lapland), Belarus, the Baltic States, Poland, most of Germany, Romania, Moldova, Ukraine, part of Bulgaria and Hungary. Single populations are also found in Sweden, Norway, the Netherlands, France, Switzerland, Austria (Kauhala 1996).

Raccoon dogs have been a component of the fauna of Poland since 1955. The population of this predator was spreading very quickly, in 1963 the raccoon dog was observed in at least 106 forest districts all over Poland, in 1971 in at least 238. In 1983 it occupied the entire north eastern and eastern Poland. Currently, it is found in large numbers throughout the country, with the exception of high altitudes in the mountains. Along with the increase in the range, the number of this species, despite intensive hunting, was constantly growing (Pucek and Raczyński 1983).

A possible cause of the described expansion of the raccoon dog is the decrease in mortality due to rabies, which these animals previously suffered from quite often. In the 1980s, the raccoon dog took second place-after the fox, on the list of animals with this disease. From the mid-1990s, the epidemiological threat began to decline due to the spread of oral vaccines designed to immunize the fox against rabies. This way, the role of one of the important mortality factors in the populations of raccoon dogs was limited (Kamieniarz and Panek 2008). The same trend in spread and similar habitat preferences of the raccoon dog and $D$. reticulatus ticks suggest an association of these phenomena. Raccoon dogs inhabit open or not very compact areas, moist deciduous and mixed forests, river valleys, lake shores and wetlands (Kauhala and Kowalczyk 2011). Ornate dog ticks occur in the same habitats, except in dense forests. Another biological feature associated with the expansion of both species is the 
tendency of raccoon dogs to take long walks in new areas. During migration, animals carry ticks attached to their skin. Annually, the raccoon can move from 150 to almost $500 \mathrm{~km}$ (Kauhala and Kowalczyk 2011; Mulder 2012). Moreover, the fact of raccoon dog hibernation has been documented, which creates favorable wintering conditions for attached meadow ticks, and the ability to hibernate on their hosts has been documented (Karbowiak et al. 2003).

\section{Red fox Vulpes vulpes}

The territorial range of this species is one of the largest among all wild predatory mammals. According to hunting reports, the number of foxes in Poland in the 1970s and 1980s was estimated at 50,000 individuals and did not change significantly until the early 1990s. From around the middle of that decade, a noticeable increase in their population began, which continued until at least 2006, with an estimated number of about 204,000 individuals. In 2007-2008, the estimates of the number of these predators gave a slightly lower result, interpreted as stabilization of the population at a high level (Kamieniarz and Panek 2008; Zalewski et al. 2018). It is assumed that the most important reason for the increase in the population of this species is the introduction of anti-rabies vaccination. Apart from changes in the number and size of the population, changes in the biology of foxes are also observed (Goszczyński et al. 2008). Their preferred habitat type is and has always been a mosaic of forests and fields. However, there is an increasing occurrence and reproduction of foxes in the agricultural landscape, near human settlements, and even in urban areas. The second change concerns food resources. At the end of the 1990s, the diet of foxes was significantly more complex than before, and was composed of a certain proportion of domestic animals, mainly carcasses and carcass remains. This type of food replaced the once important prey, mainly hares, but also black grouse, which became less accessible to foxes due to a significant decline in their numbers in the 1990s. (Goszczyński et al. 2008; Panek and Budny 2017).

The positive effect of vaccination against rabies on the increase in the fox population was observed not only in Poland - a similar trend was reported in Germany (Vos 1995).

\section{The role of the hosts in the expansion of $D$. reticulatus}

Until the end of the twentieth century, the European elk ( $A$. alces) was considered by many authors the most important host of the adult $D$. reticulatus ticks, due to the high infestation and overlapping range of both species (Dróżdż 1963; Kadulski 1989; Siuda 1993). It was confirmed by the large number of ticks collected from elk, similar habitat preferences and the overlapping of the elk area with the location of the most numerous populations of $D$. reticulatus (Dróżdż 1963, 1964; Szymański 1986; Kadulski 1989; Siuda 1993). Unfortunately, apart from the reports on the high prevalence and intensity of $D$. reticulatus infestation, none of the authors published detailed data. Only Bogdaszewska (2004, 2005), on the basis of the available individual animals, reported the prevalence from 75 to $100 \%$. Due to the lack of systematic observations, it is difficult to say whether the spread of elk by the end of the 1980s in the northern and western parts of Poland could have contributed to the emergence of $D$. reticulatus populations. Ornate dog ticks were observed in the Kampinos Forest and West Pomeranian Voivodeship in the late 1990s (Szczurek 2001), i.e. before the assumed beginning of expansion, as well as in the Pomeranian Voivodeship at the beginning of its expansion, from the west to the border of the area of occurrence (Kadulski and Izdebska 2009). An undoubted relationship is the rapid, twofold increase in the number of elk in the first decade of the twenty-first century and the spread to previously rare areas, with the simultaneous increase in the population of ornate dog ticks and the emergence of their new habitats in the Masurian Lake District (Kamieniarz and Panek 2008; Kadulski and Izdebska 2009; Karbowiak 2014; Mierzejewska et al. 2016; Kubiak et al. 2018).

Red deer have always been numerous in Poland, but as hosts of adult $D$. reticulatus, they were recognized in the last decade of twentieth century, after intensive research on this species (Kadulski 1989; Dróżdż and Bogdaszewska 1997; Bogdaszewska 2005). These animals were common throughout the country, but the most numerous populations were found in the north-eastern regions, and strong tick populations were found at the same sites. Their role as hosts of $D$. reticulatus is indicated by the fact that numerous populations of ornate dog ticks survived in Poland in the postwar period, when elk practically did not occur. Recognition of the elk as the main host is also problematic due to the presence of $D$. reticulatus in western Germany and France, where this species of mammal has not been present in the wild for many decades. Specific data on the prevalence and the intensity of cervid infestation by $D$. reticulatus are rare but known. The increase in the number of these animals in recent decades may have contributed to the expansion of $D$. reticulatus, providing them with a food base. The aforementioned increase in the number of red deer in south-western Poland may be related to the emergence of new D. reticulatus outbreaks in this part of the country in 2000 and 2010 (Nowak 2011; Kiewra and Czułowska 2013). In the Lublin region, the infestation of red deer with $D$. reticulatus ticks in 2000 was $31.2 \%$ to $36.4 \%$ and was higher in bulls-36.9\%than in the case of females- $15.4 \%$. The authors noted that the infestation level differs depending on the region; it was 
higher in the northern and eastern parts of the region, which was consistent with the reported range of the tick (Biadun and Najda 2007).

The role of predatory mammals as hosts of $D$. reticulatus was appreciated in the latest decades only (Kočišová et al. 2006; Karbowiak et al. 2020). Carnivores are important hosts for immature as well as adult stages of ticks. Most studies report a mixed fauna of ticks on these animals. The common tick $I$. ricinus is the most common, followed by Ixodes canisuga Johnston, 1849 (also known as I. crenulatus Koch, 1844), Ixodes hexagonus Leach, 1815, D. reticulatus, and Haemaphysalis concinna Koch, 1844 in the south to the Carpathians. The infestation of foxes with D. reticulatus is the most variable. In Slovakia it reached $17.9 \%$ (Kočišová et al. 2006), in Poland 60.0\% (Karbowiak et al. 2016, 2020), in Hungary 27\% (Sréter et al. 2003). Until now, this tick has been considered rare in Germany, even in Berlin this tick was not found on foxes (Schöffel et al. 1991). The last time when a low level of infestation of foxes was recorded, was in Thuringia, Germany, where the incidence of these ticks was $0.29 \%$ (Meyer-Kayser et al. 2012).

The host's competence, biology and spread to new areas allow the raccoon dog to be included in the set of factors favoring the development of $D$. reticulatus ticks. Research conducted on raccoon dogs in the Augustów Primeval Forest in north-eastern Poland showed the presence of $D$. reticulatus infestation in above $39.3 \%$ of the animals, with an intensity of up to 20 ticks per individual. At the same time, there was a strong competition from the common tick I. ricinus (frequency $44.7 \%$, intensity up to 40 individuals) (Karbowiak et al. 2016). Ticks attack these animals practically throughout the growing season. In earlier, single observations, more than 50 ornate dog ticks were found on a single raccoon dog, with no competition from other ticks. Therefore, it was confirmed that the raccoon dog is a competent host for the ornate dog tick (Karbowiak, unpbl.). Other species of ticks - the dog tick I. crenulatus and the hedgehog tick I. hexagonus, were found to infest a lower percentage of these animals (Karbowiak et al. 2016, 2020).

The role of red foxes and raccoon dogs as hosts for ticks does not differ significantly, it can be concluded that their infestation depends more on the presence of ticks in the environment than on the preferences of the host. Both species of mammals are characterized by a similar high mobility, ability to walk and the fact of a huge increase in the population size, which coincided with the increase in the number and expansion of $D$. reticulatus.

The direction of the spread of the raccoon dog is consistent with the expansion of the $D$. reticulatus tick in Poland. The first individuals of this predator appeared in Podlasie and Roztocze (Kauhala and Kowalczyk 2011), i.e. in the primary outbreak areas of this tick in Poland (Dróżdż 1963; Siuda 1993). At the same time, Dróżdż (1964) observed the fall of foxes and raccoon dogs in the spring, which he associated on the base of clinical symptoms with the appearance of D. reticulatus ticks and the piroplasms they transmit - unfortunately, he did not confirm the diagnosis by laboratory tests. The rate of expansion of the raccoon dog, of course, is well ahead of the expansion rate of the tick as the latter is dependent on the former. On the other hand, it takes at least many years for a new species of mammals to become a significant host for the parasite and, above all, to create a sufficiently large population (Fig. 1).

Overall, the increase in the host population contributed to an increase in the pre-expansion tick population density. Eastern Poland is a good example. In the 1960s, there were few ornate dog ticks in the vicinity of Lublin (Dutkiewicz and Siuda 1969), now it is the most common tick species (Zajac et al. 2020). The same explanation may also be applied to the population growth of $D$. reticulatus in the Masurian Lake District (Kubiak et al. 2018). Biaduń and Najda (2007) noted the appearance of ornate dog ticks on red deer in 2007 near Piotrków Trybunalski, east of the San River, considered to be the western border of this tick in Poland. A similar result was obtained in Germany, also in the 2000s-D. reticulatus ticks were found on the heads of red deer obtained from towns in Brandenburg, Saxony-Anhalt,

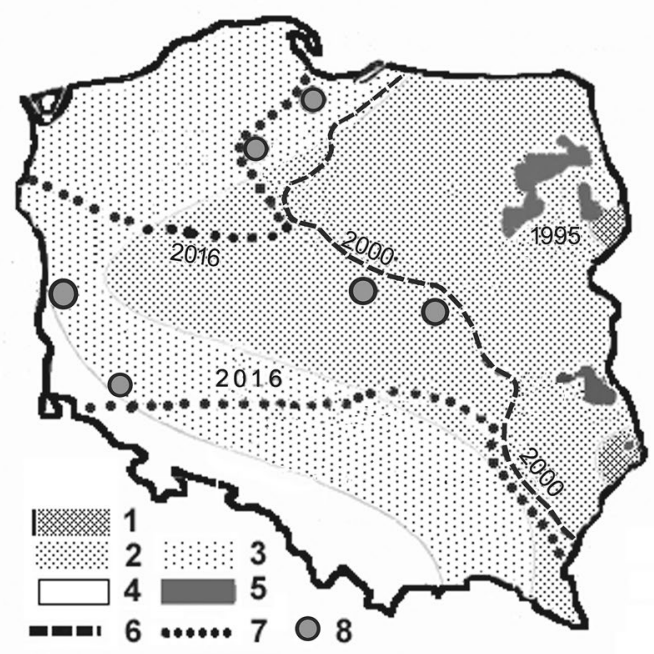

Fig. 1 The expansion of Nyctereutes procyonoides and Dermacentor reticulatus in Poland. 1 - the expansion range of raccoon dog in $1955 ; 2$ - the expansion range of raccoon dog in 1955-1960; 3 - the expansion range of raccoon dog in 1960-1965; 4 - the expansion range of raccoon dog after 1965 (according to Kamieniarz and Panek 2008; Kauhala and Kowalczyk 2011); 5 - the known localities of $D$. reticulatus before 1995; 6 - the known range of $D$. reticulatus until 2000; 7 - the known range of D. reticulatus until 2016; 8 - the new records between 2000-2021 
Hesse and Bavaria, where the tick had not been found before (Dautel et al. 2006).

The latest reports confirmed the existence of large mammals as carriers, as well as a tool supporting the development of the newly emerging population of the ornate dog tick in the Lubuskie voivodeship, where the prevalence of infestation of red deer and wild boars with these ticks was almost 100\% (Ciebiera et al. 2021).

Due to the growing number of individuals, all the abovementioned species of mammals are looking for new habitats. As a result, they enter inhabited and developed areas, including recreational areas of cities (Bateman and Fleming 2012; Krauze-Gryz et al. 2016, 2020). The invasion of foxes into cities may be a factor that probably explains the emergence of new $D$. reticulatus outbreaks in large urban agglomerations. The emergence of new populations within the city limits, where ticks were previously absent, has been documented in Warsaw (Supergan and Karbowiak 2009; Karbowiak 2014). However, the role of large herbivores in cities in the reproduction of ticks is limited. They stay mainly on the outskirts of cities, in places directly related to suburban forests, and periodically visit city parks. A limited number of ticks can only be brought into cities with these hosts. The fox and the raccoon dog, thanks to their smaller size and greater behavioral plasticity, are able to permanently inhabit areas transformed by humans. In addition, they are able to overcome architectural barriers such as roads and fences. Therefore, they become an important factor in the survival of D. reticulatus populations in urban areas. A beneficial factor, seemingly not intricately related to the above, is the creation of ecological corridors for animals through landscape areas. Ecological corridors favor the expansion of many animal species, including predators, wild boars and external parasites carried on their bodies. This happens in many cities with rivers flowing. The strands of trees, as well as vast parks with varied vegetation, serve as a migration route for many species of wild animals through the city, with which the migrating ticks attach to their bodies. Dense downtown clusters of trees and shrubs create a local microclimate with lower temperatures and higher humidity than built-up areas (Szumacher 2005). This allows some animal species to live permanently in cities, and the engorged female ticks can lay eggs and develop larvae. The larvae are the beginning of new tick populations in human-inhabited areas.

The role of hosts in the expansion of D. reticulatus described above mainly concerns the territory of Poland, as a result of the analysis of Polish literature sources. In neighboring countries, hosts also must play an important role, but this may vary due to local differences in their numbers, and the simultaneous influence of other factors, such as local natural, climatic and geographical conditions (Karbowiak 2014; Földvári et al. 2016; Mierzejewska et al. 2016). To sum up, both elk and raccoon dog can play a big role in the countries north-east of Poland, where they are still numerous, but they do not have any role in Western Europe and south of the Carpathian Mountains, because they simply are rare or absent there (Schönfeld 2009; Bragina et al. 2018).

Declarations Not applicable.

Ethical approval The studies described were in compliance with all ethical principles.

Informed consent Not applicable.

Conflict of Interest As the corresponding author I state that there is no conflict of interest.

Open Access This article is licensed under a Creative Commons Attribution 4.0 International License, which permits use, sharing, adaptation, distribution and reproduction in any medium or format, as long as you give appropriate credit to the original author(s) and the source, provide a link to the Creative Commons licence, and indicate if changes were made. The images or other third party material in this article are included in the article's Creative Commons licence, unless indicated otherwise in a credit line to the material. If material is not included in the article's Creative Commons licence and your intended use is not permitted by statutory regulation or exceeds the permitted use, you will need to obtain permission directly from the copyright holder. To view a copy of this licence, visit http://creativecommons.org/licenses/by/4.0/.

\section{References}

Akimov IA, Nebogatkin IV (2002) Iksodovyye klyeshchi g. Kiyeva urbozoologicheskiye i epizootologichyeskiye aspekty. Vest Zool 36:91-95

Akimov IA, Nebogatkin IV (2011) Distribution of ticks from of the genus Dermacentor (Acari; Ixodidae) in Ukraine. Vest Zool 45:35-40

Bateman P, Fleming P (2012) Big city life: carnivores in urban environments. J Zool 287:1-23. https://doi.org/10.1111/j.1469-7998. 2011.00887.x

Bauch R (1990) Ixodes ricinus, Haemaphysalis concinna und Dermacentor reticulatus (Ixodida, Ixodidae) im DDR-Bezirk Leipzig. Angew Parasitol 31:57-64

Biaduń W, Najda N (2007) Jeleń Cervus elaphus jako żywiciel kleszcza łąkowego Dermacentor reticulatus w Polsce ŚrodkowoWschodniej. Wiad Parazytol 53(Suppl):136

Błażejczyk K (2006) Climate and bioclimate of Poland. In: Degórski M (ed) Natural and human environment of Poland. A geographical overview. Instytut Geografii i Przestrzennego Zagospodarowania im. S.Leszczyckiego, Polskie Towarzystwo Geograficzne, Warsaw, pp 31-48

Bogdaszewska Z (2004) Występowanie i ekologia kleszcza łąkowego Dermacentor reticulatus (Fabricius, 1794) w ognisku mazurskim. I. Określenie obecnego zasięgu występowania. Wiad Parazytol 50:727-730

Bogdaszewska Z (2005) Występowanie i ekologia kleszcza łąkowego Dermacentor reticulatus (Fabricius, 1794) w ognisku mazurskim. IV. Wyniki badań nad określeniem specyficzności żywicielskiej. Wiad Parazytol 51:39-42

Bragina EV, Ives AR, Pidgeon AM, Balčiauskas L, Csányi S, Khoyetskyy P, Kysucká K, Lieskovsky J, Ozolins J, Randveer T, Štych P, 
Volokh A, Zhelev C, Ziółkowska E, Radeloff VC (2018) Wildlife population changes across Eastern Europe after the collapse of socialism. Front Ecol Environ 16:77-81. https://doi.org/10.1002/ fee. 1770

Brovko SM (1966) K ekologii i rasprostraneniy iksodovykh kleshchey v lesnyh nasazhdeniakh stepnoj zony Ukrainy. Tezisy Dokl 1 Akarol Soveshch, pp 42-43

Budny M, Bresiński W, Kamieniarz R, Kolanoś B, Mąka H, Panek M (2011) Sytuacja zwierząt łownych w Polsce w roku łowieckim 2010/2011 (wyniki monitoringu). Biuletyn Stacji Badawczej w Czempiniu Nr 8. OHZ PZŁ Czempiń

Bullová E, Lukáň M, Stanko M, Petko B (2009) Spatial distribution of Dermacentor reticulatus tick in Slovakia in the beginning of the 21st century. Vet Parasitol 165:357-360. https://doi.org/10. 1016/j.vetpar.2009.07.023

Chigirik ED, Pleshivtseva-Eroshkina EA (1969) Ixodove kleshchi Kemerovoy Oblasti. Med Parazitol (Mosk) 38:423-426

Ciebiera O, Łopińska A, Gabryś G (2021) Ticks on game animals in the fragmented agricultural landscape of western Poland. Parasitol Res 120:1781-1788. https://doi.org/10.1007/s00436-021-07132-9

Cuber P, Solarz K, Mosiałek A, Jakubiec-Spanier M, Spanier A (2013) The first record and occurrence of the ornate cow tick Dermacentor reticulatus (Fabricius, 1794) in south-western Poland. Ann Parasitol 59:49-51

Daniel M, Černý V, Szymański S (1986) A comparison of factors influencing the distribution of Dermacentor reticulatus (Ixodidae) in Czechoslovakia and Poland. Wiad Parazytol 32:355-361

Dautel H, Dippel C, Oehme R, Hartelt K, Schettler E (2006) Evidence for an increased geographical distribution of Dermacentor reticulatus in Germany and detection of Rickettsia sp. RpA4. Int J Med Microbiol 296(S1):149-156. https://doi.org/10.1016/j.ijmm.2006. 01.013

Dróżdż J (1963) Występowanie kleszczy z rodzaju Dermacentor w Polsce. Wiad Parazytol 9:57-60

Dróżdż J (1964) Dalsze dane o Dermacentor pictus Herm. i kwestia piroplazmozy koni w Polsce. Wiad Parazytol 10:590-591

Dróżdż J, Bogdaszewska Z (1997) Ognisko Dermacentor reticulatus podtrzymywane przez jelenie i daniele w hodowli fermowej (Kosewo, Polska). Wiad Parazytol 43:207-212

Dróżdż J, Demiaszkiewicz AW, Lachowicz J (2002) Exchange of gastrointestinal nematodes between roe and red deer (Cervidae) and European bison (Bovidae) in the Bieszczady Mountains (Carpathians, Poland). Acta Parasitol 47:314-317

Dutkiewicz J, Siuda K (1969) Nowe stanowisko kleszczy Dermacentor pictus Herm. w południowej Lubelszczyźnie. Med Wet 25:44-47

Estrada-Peña A, Mihalca D, Petney T (2017) Ticks of Europe and North Africa. A Guide to Species Identification. Springer International Publishing

Földvári G, Široký P, Szekeres S, Majoros G, Sprong H (2016) Dermacentor reticulatus: a vector on the rise. Parasit Vectors 9:314. https://doi.org/10.1186/s13071-016-1599-x

Gilot B, Pautou G, Immler R, Moncada E (1973) Biotopes suburbains à Dermacentor reticulatus (Fabricius, 1794) (Ixodoidea). Revue Suisse Zool 80:411-430

Goszczyński J, Misiorowska M, Juszko S (2008) Changes in the density and spatial distribution of red fox dens and cub numbers in central Poland following rabies vaccination. Acta Theriol 53:121-127. https://doi.org/10.1007/BF03194245

Gray JS, Dautel H, Estrada-Peña A, Kahl O, Lindgren E (2009) Effects of climate change on ticks and tick-borne diseases in Europe. Interdiscip Perspect Infect Dis 2009:593232. https://doi.org/10. $1155 / 2009 / 593232$

Guglielmone AA, Robbins RG, Apanaskevich DA, Petney T, Estrada-Peña A, Horak IG (2014) The hard ticks of the World (Acari: Ixodida: Ixodidae). Springer Science \& Business Media, Dordrecht Heidelberg New York London
Hasle G (2013) Transport of ixodid ticks and tick-borne pathogens by migratory birds. Front Cell Infect Microbiol 3:48. https://doi. org/10.3389/fcimb.2013.00048

Heltai M, Szemethy L, Lanszki J, Csányi S (2000) Returning and new mammal predators in Hungary: the status and distribution of the golden jackal (Canis aureus), raccoon dog (Nyctereutes procyonides) and raccoon (Procyon lotor) in 1997-2000. Beitr Jagd Wildforsch 26:95-102

Immler RM (1973) Untersuchungen zur Biologie und Ökologie der Zecke Dermacentor reticulatus (Fabricius, 1794) (Ixodidae) in einem endemischen Vorkommensgebiet. Mitt Schweiz Entomol Ges 46:2-70

Kadulski S (1989) Występowanie stawonogów pasożytniczych na łownych Lagomorpha i Artiodactyla - próba syntezy. Zeszyty Naukowe. Uniwersytet Gdański, Rozprawy i Monografie. 132. Wydawnictwo Uniwersytetu Gdańskiego

Kadulski S, Izdebska JN (2009) New data on distribution of Dermacentor reticulatus (Fabr.) (Acari, Ixodidae) in Poland. In: Buczek A, Błaszak Cz (eds) Stawonogi. Inwazje i ich ograniczanie. Akapit, Lublin

Kamieniarz R, Panek M (2008) Zwierzęta łowne w Polsce na przełomie XX i XXI wieku. OHZ PZŁ, Czempiń

Karbowiak G (2014) The occurrence of the Dermacentor reticulatus tick - its expansion to new areas and possible causes. Ann Parasitol 60:37-47

Karbowiak G, Demiaszkiewicz AW, Pyziel AM, Wita I, Moskwa B, Werszko J, Bień J, Goździk K, Lachowicz J, Cabaj W (2014) The parasitic fauna of the European bison (Bison bonasus) (Linnaeus, 1758) and their impact on the conservation. Part 2. The structure and changes over time. Acta Parasitol 59:372-379. https://doi.org/10.2478/s11686-014-0253-z

Karbowiak G, Izdebska JN, Czaplińska U, Wita I (2003) Przypadki zimowania kleszczy z rodziny Ixodidae na żywicielach w Puszczy Białowieskiej. In: Buczek A, Błaszak Cz (eds) Stawonogi i żywiciele. Liber, Lublin

Karbowiak G, Kiewra D (2010) New locations of Dermacentor reticulatus ticks in Western Poland: the first evidence of the merge in $D$. reticulatus occurrence areas? Wiad Parazytol $56: 333-340$

Karbowiak G, Siuda K (2001) Występowanie kleszcza pospolitego Ixodes ricinus (Acari: Ixodida) na terenach rekreacyjnych dużych aglomeracji miejskich w Polsce i jego znaczenie epidemiologiczne. In: Indykiewicz P, Barczak T, Kaczorowski G (eds) Bioróżnorodność i ekologia populacji zwierzęcych w środowiskach zurbanizowanych. NICE, Bydgoszcz, pp $150-154$

Karbowiak G, Stanko M, Miterpaková M, Hurníková Z, Víchová B (2020) Ticks (Acari: Ixodidae) parasitizing red foxes (Vulpes vulpes) in Slovakia and new data about subgenus Pholeoixodes occurrence. Acta Parasitol 65:636-643. https://doi.org/10.2478/ s11686-020-00184-4

Karbowiak G, Szewczyk T, Werszko J (2016) Ectoparasites of carnivores in north-eastern Poland. Ann Parasitol 62(Suppl):184

Kauhala K (1996) Introduced carnivores in Europe with special reference to central and northern Europe. Widlife Biol 2:197-204. https://doi.org/10.2981/wlb.1996.019

Kauhala K, Kowalczyk R (2011) Invasion of the raccoon dog Nyctereutes procyonoides in Europe: History of colonization, features behind its success, and threats to native fauna. Current Zool 57:584-598. https://doi.org/10.1093/czoolo/57.5.584

Kiewra D, Czułowska A (2013) Evidence for an increased distribution range of Dermacentor reticulatus in south-west Poland. Exp Appl Acarol 59:501-506. https://doi.org/10.1007/ s10493-012-9612-3

Koch CL (1844) Systematische Übersicht über die Ordnung der Zecker. Archiv Naturgeschichte 10:217-239 
Kočišová A, Lazar P, Letková V, Čurlík J, Goldová M (2006) Ectoparasitic species from red foxes (Vulpes vulpes) in East Slovakia. Vet Arhiv 76(Suppl):S59-S63

Krauze-Gryz D, Lesiński G, Pieniążek A, Romanowski J, Owsianka M, Prus M (2016) Ssaki Parku Skaryszewskiego w Warszawie. In: Romanowski J (ed) Park Skaryszewski w Warszawie-przyroda i użytkowanie. UKSW Press, Warsaw, pp 215-226

Krauze-Gryz D, Gryz J, Wrotek N, Zosicz M (2020) Występowanie wybranych gatunków ssaków na terenie parku Pole Mokotowskie w Warszawie. Prace i Studia Geograficzne, Wydział Geografii i Studiów Regionalnych Uniwersytetu Warszawskiego 65.1:97-103

Kubiak K, Sielaw H, Dziekońska-Rynko J, Kubiak D, Rydzewska M, Dzika E (2018) Dermacentor reticulatus ticks (Acari: Ixodidae) distribution in north-eastern Poland: an endemic area of tick-borne diseases. Exp Appl Acarol 75:289-298. https://doi.org/10.1007/ s10493-018-0274-7

Labuda M, Lysý J, Krippel E (1989) Kliešte Ixodes ricinus, Haemaphysalis concinna a Dermacentor reticulatus (Acarina, Ixodidae) na drobných zemných cicavcoch vybraných lokalít západného Slovenska. Biológia 44:897-909

Mačička O, Nosek J, Rosický B (1956) Poznámky k bionómii, vývoju a hospodárskemu významu pijaka lužného (Dermacentor pictus Herm.) w strednej Európe. Vydavatel'stvo SAV, Bratislava

Martinod S, Gilot B (1991) Epidemiology of canine babesiosis in relation to the activity of Dermacentor reticulatus in southern Jura (France). Exp Appl Acarol 11:215-222. https://doi.org/10.1007/ bf01246093

Matuszkiewicz JM (2006) Poland's flora and fauna. In: Degórski M (ed) Natural and human environment of Poland. A geographical overview. Instytut Geografii i Przestrzennego Zagospodarowania im. S.Leszczyckiego, Polskie Towarzystwo Geograficzne, Warsaw, pp 77-92

Metianu T (1951) Contribution a l'étude des ixodides de Roumanie. Ann Parasitol Hum Comp 26:446-463

Meyer-Kayser E, Hoffmann L, Silaghi C, Pfister K, Mahling M, Passos LM (2012) Dynamics of tick infestations in foxes in Thuringia, Germany. Ticks Tick Borne Dis 3:232-239. https://doi.org/10. 1016/j.ttbdis.2012.05.004

Mierzejewska EJ, Estrada-Peña A, Alsarraf M, Kowalec M, Bajer A (2016) Mapping of Dermacentor reticulatus expansion in Poland in 2012-2014. Ticks Tick Borne Dis 7:94-106. https://doi.org/10. 1016/j.ttbdis.2015.09.003

Mulder JP (2012) A review of the ecology of the raccoon dog (Nyctereutes procyonoides) in Europe. Lutra 55:101-127

Nowak M (2011) Discovery of Dermacentor reticulatus (Acari: Amblyommidae) populations in the Lubuskie Province (Western Poland). Exp Appl Acarol 54:191-197. https://doi.org/10.1007/ s10493-010-9422-4

Nowak E, Pielowski Z (1964) Die Verbreitung des Marderhundes in Polen im Zusammenhang mit seiner Einbürgerung und Ausbreitung in Europa. Acta Theriol 9:81-110

Nowak-Chmura M (2013) Fauna of ticks (Ixodida) of Central Europe. Scientific Publishing house of the Pedagogical University of Cracow, Cracow

Panas E, Léger N, Kretz J-L, Dumesnil C (1976) Les ixodidae de la région Champagne-Ardennes. Étude préliminaire. Acarologia 18:51-55

Panek M, Budny M (2017) Variation in the feeding pattern of red foxes in relation to changes in anthropogenic resource availability in a rural habitat of western Poland. Mammal Biol 82:1-7. https://doi. org/10.1016/j.mambio.2016.09.002

Paulauskas A, Radzijevskaja J, Mardosaitė-Busaitienè D, Aleksandravičienè A, Galdikas M, Krikštolaitis R (2015) New localities of Dermacentor reticulatus ticks in the Baltic countries. Ticks Tick Borne Dis 6:630-635. https://doi.org/10.1016/j.ttbdis. 2015.05.007
Pucek Z, Raczyński J (1983) Atlas rozmieszczenia ssaków w Polsce. Atlas of Polish Mammals. PWN, Warszawa

Ravdonikas OV, Solovey EA, Chumakov MP, Korsh IV, Ivanov DI (1968) Prirodnye ochagi omskoy gemorragicheskoy likhoradki v svetle landshaftnogo areala rasprostraneniya svoystv bolezni. Mater 3 Nauch Soveshch. Probl Med Geogr (Leningrad, November 1968): $152-154$

Savitsky BP, Kulnazarov BK (1988) Ektoparazity i forezanty polevkiekonomki (Microtus oeconomus Pall.) v Poles'e. Parazitologija 22:372-377

Schöffel I, Schein E, Wittstadt U, Hentsche J (1991) Zur Parasitenfauna des Rotfuchses in Berlin (West). Berl Münch Tierärztl Wschr 104:153-157

Schönfeld F (2009) Presence of moose (Alces alces) in Southeastern Germany. Eur J Wild Res 55:449-453. https://doi.org/10.1007/ s10344-009-0272-5

Siuda K (1993) Kleszcze Polski (Acari: Ixodida). II. Systematyka i rozmieszczenie. Polskie Towarzystwo Parazytologiczne, Warszawa

Siuda K (1995) The review of data on the distribution of Ixodida (Acari) in Poland. In: Kropczyńska D, Boczek J, Tomczyk A (eds) The acari. Physiological and ecological aspects of acari-host relationships. Oficyna Dabor, Warsaw, pp 273-280

Siuda K, Zięba P, Bogdaszewska Z, Stańczak J, Sebesta R (1997) Review of data of the distribution of Dermacentor reticulatus (Fabricius 1794) (Acari: Ixodida: Ixodidae ) in Poland. Zesz Nauk (Ochrona Środowiska) Akademii Technologiczno-Przyrodniczej w Bydgoszczy 2:155-160

Široký P, Kubelová M, Bednář M, Modrý D, Hubálek Z, Tkadlec E (2011) The distribution and spreading pattern of Dermacentor reticulatus over its threshold area in the Czech Republic - how much is range of this vector expanding? Vet Parasitol 183:130-135. https://doi.org/10.1016/j.vetpar.2011. 07.006

Sréter T, Széll Z, Varga I (2003) Ectoparasite infestations of red foxes (Vulpes vulpes) in Hungary. Vet Parasitol 115:349-354. https:// doi.org/10.1016/s0304-4017(03)00216-4

Sréter T, Széll Z, Varga I (2005) Spatial distribution of Dermacentor reticulatus and Ixodes ricinus in Hungary: evidence for change? Vet Parasitol 128:347-351. https://doi.org/10.1016/j.vetpar.2004. 11.025

Supergan M, Grytner-Zięcina B, Karbowiak G, Hapunik J (2008) Rozmieszczenie kleszczy w lasach i parkach aglomeracji warszawskiej. In: Buczek A, Cz Błaszak (eds) Stawonogi. Oddziaływanie na żywiciela. Akapit, Lublin, pp 63-71

Supergan M, Karbowiak G (2009) The estimation scale of endangerment with tick attacks on recreational towns areas. Przegląd Epidemiol 63:67-71

Szczurek B (2001) Pasożytnicze Acari daniela (Dama dama) z Pojezierza Pomorskiego. Wiad Parazytol 47(Suppl 2):54

Széll Z, Sréter-Lancz Z, Márialigeti K, Sréter T (2006) Temporal distribution of Ixodes ricinus, Dermacentor reticulatus and Haemaphysalis concinna in Hungary. Vet Parasitol 141:377-379. https:// doi.org/10.1016/j.vetpar.2006.06.008

Szumacher I (2005) Funkcje ekologiczne parków miejskich. Prace i Studia Geograficzne 36:107-120

Szymański S (1986) Distribution of the tick Dermacentor reticulatus (Fabricius, 1794) (Ixodidae) in Poland. Acta Parasitol Pol $31: 143-154$

Wall R (2012) A ticking clock for tickborne disease? Vet Rec 170:326-328

Vos A (1995) Population dynamics of the red fox (Vulpes vulpes) after the disappearance of rabies in county Garmisch-Partenkirchen, Germany, 1987-1992. Ann Zool Fennici 32:93-97 
Zając Z, Woźniak A, Kulisz J (2020) Density of Dermacentor reticulatus ticks in Eastern Poland. Int J Env Res Public Health 17:2814. https://doi.org/10.3390/ijerph17082814

Zając Z, Sędzikowska A, Maślanko W, Woźniak A, Kulisz J (2021) Occurrence and abundance of Dermacentor reticulatus in the habitats of the ecological corridor of the Wieprz River. Eastern Poland Insects 12:96. https://doi.org/10.3390/insects12020096
Zalewski D, Okarma H, Panek M (2018) Monitoring liczebności i jakości populacji dzikich zwierząt. Uniwersytet WarmińskoMazurski. Katedra Hodowli Zwierząt Futerkowych i Łowiectwa, Olsztyn

Publisher's note Springer Nature remains neutral with regard to jurisdictional claims in published maps and institutional affiliations. 